Article

\title{
Student Choice in Higher Education-Reducing or Reproducing Social Inequalities?
}

\author{
Claire Callender ${ }^{1, *}$ and Kevin J. Dougherty ${ }^{2}$ \\ 1 Institute of Education, University College London and Birkbeck, University of London, 26 Russell Square, \\ London WC1B 5DQ, UK \\ 2 Teachers College, Columbia University, Box 11, 525 W. 120th St., New York, NY 10027, USA; \\ doughertykevin@tc.columbia.edu \\ * Correspondence: c.callender@bbk.ac.uk; Tel.: +44-207-631-6624
}

Received: 2 August 2018; Accepted: 17 September 2018; Published: 9 October 2018

check for updates

\begin{abstract}
A hallmark of recent higher education policy in developed economies is the move towards quasi-markets involving greater student choice and provider competition, underpinned by cost-sharing policies. This paper examines the idealizations and illusions of student choice and marketization in higher education policy in England, although the overall conclusions have relevance for other countries whose higher education systems are shaped by neoliberal thinking. First, it charts the evolution of the student-choice rationale through an analysis of government commissioned reports, white papers, and legislation, focusing on policy rhetoric and the purported benefits of increasing student choice and provider competition. Second, the paper tests the predictions advanced by the student-choice rationale-increased and wider access, improved institutional quality, and greater provider responsiveness to the labour market-and finds them largely not met. Finally, the paper explores how conceptual deficiencies in the student-choice model explain why the idealization of student choice has largely proved illusionary. Government officials have narrowly conceptualized students as rational calculators primarily weighing the economic costs and benefits of higher education and the relative quality of institutions and programs. There is little awareness that student choices are shaped by several other factors as well and that these vary considerably by social background. The paper concludes that students' choices are socially constrained and stratified, reproducing and legitimating social inequality.
\end{abstract}

Keywords: higher education; social inequality; choice; quasi-markets; student financial aid; part-time students; marketization; neoliberalism

\section{Introduction}

A hallmark of much recent higher education (HE) policy in developed economies is the move towards the creation of quasi-markets through policies seeking to promote student choice and provider competition, what has been called the "marketisation of higher education" (Brown 2013; Marginson 2009). Governments have advanced the argument that HE institutions, as with other public-welfare organizations, work best if their actions are driven by the decisions of empowered consumers, whether students or other clients, operating within a market or quasi-market. HE institutions will be more responsive to the needs of students, the labor market, and society if students are a direct source of revenue through tuition payments and if institutions face more competition from each other. Additionally, students will make choices that better accord with their interests if they have a direct interest in HE quality and outcomes because they are paying for their education (see Brown 2012, 2013, 2015, 2018; Marginson 2009, 2016a, 2016b; Naidoo 2016; Naidoo et al. 2011; Slaughter and Rhoades 2004). 
In the UK, this student-choice argument arose as part of the general movement of UK government toward a more marketized policy regime under the aegis of the neoliberal political and economic philosophy that was first espoused by the Thatcher Government and then followed by its successors (Brown 2012, 2013, 2015, 2018; Deem 2001; Feigenbaum et al. 1998; Harvey 2005; Naidoo et al. 2011; Olssen and Peters 2005). The neoliberal argument is that human well-being is best ensured by encouraging private enterprise and individual responsibility and by having competitive markets spur and coordinate the actions of those entrepreneurs (Harvey 2005; Olssen and Peters 2005). The key role of government is to bolster the free operation of markets and private enterprise and to keep government intervention in the market at a minimum (Brown 2018; Harvey 2005; Olssen and Peters 2005). Government operations should be privatized as much as possible by selling public holdings and services to private entrepreneurs. However, when this is not possible, governments should enmesh public agencies in "quasi-markets" by creating fiscal incentives to compete with each other to become more efficient (Dill 2007; Le Grand 2007; Marginson 2009; Olssen and Peters 2005; Naidoo et al. 2011). These public services should be funded increasingly through charges to the users such as students, who become seen as the main beneficiaries of HE rather than society as a whole (Altbach 1999); this will allow releasing public funds to other government services and-through tax reductions—to business investment (Brown 2015, 2018; Harvey 2005; Slaughter and Rhoades 2016).

This paper examines the idealization and illusions of student choice and marketization in HE policy. It does so in three steps. First, the paper explores the evolution of the student-choice and marketization rationale in England in relation to undergraduate HE through analysis of commissioned reports, white papers, and legislation. It focuses on the evolving idealization of student choice in policy rhetoric as policy ideologues developed arguments for the benefits of increasing student choice and market forces in HE. What follows is an examination of the illusions of choice. In the second step, the paper tests the specific predictions for the future of HE that the elaborators of the student-choice rationale have advanced. Has the English experience validated the predictions that the new student-choice and marketization regime will produce higher participation levels for both full-time and part-time undergraduate students, greater equality of access by social background both to HE as a whole and different types of institutions, increased institutional quality, and greater institutional labour market responsiveness? Moreover, has the new student-choice regime worked through the posited mechanisms of greater student use of loans and greater variety of institutional provision? As we will show, these forecasts have only been partially met and these failings indicate that there may be substantial deficiencies in the student-choice and marketization model. The third step examines these conceptual deficiencies in detail. The paper draws on the work of Pierre Bourdieu, Roger Brown, and others to examine the role of information inequality, class and race-differentiated habitus, and other factors that the conventional student-choice model did not incorporate or only partially addressed in order to show how these omissions explain why the development of the English HE system has conformed poorly to the expectations of those idealizing student choice and market forces.

This paper focuses on England but has relevance for other countries such as the US with marketized systems of higher education that seek to promote student choice (Slaughter and Rhoades 2016). Indeed, the choice processes and mechanisms discussed in this paper that reproduce social inequalities are evident as well within and across diverse contexts nationally and internationally. For instance, they are apparent in secondary or K-12 public education both in England and the US and have been the focus of much research, policy debate, and discourse (Burgess 2016; Labaree 2012). In fact, issues about student choice and its effects have received far more attention in relation to secondary education than higher education. This article attempts to redress that imbalance. Furthermore, this article seeks to broaden the scope of discussion on student choice and the marketization of higher education. Most existing research tends to focus on one dynamic and question-namely, are students customers or consumers? Here we broaden the canvass quite considerably first, through our detailed analysis of the evolution of student choice in government documents and policy rhetoric, a new contribution to the existing literature. Secondly, we pay 
particular attention to the role of cost sharing, thus exploring the policy mechanisms employed to promote student choice. Again, this is a novel approach as other work on cost sharing rarely links it to the choice agenda. Instead, evaluations of cost sharing policies for students, such as tuition fees and student loans, have tended to focus on their impact on HE access, persistence and completion for full-time undergraduates only. Thirdly, here we are concerned with a fuller range of purported benefits of student choice and for a wider group of students. We assess, based on empirical evidence, claims made about improved institutional quality, and greater $\mathrm{HE}$ responsiveness to the labour market, for both full and part-time undergraduates. Finally, our original contribution can be found in our critique of the theoretical sparseness of the student-choice concept as elaborated by policy makers, underpinned by our review of major policy documents and the assessment of a range of claims made about the benefits of student choice by its proponents.

\section{Emergence of The Rationale for Greater Student Choice And Marketization of HE}

The argument for greater student choice and a more marketized HE system holds that if students are converted into empowered and self-interested consumers they will be able to make choices that better accord with their interests and those of society because they have a direct interest in the outcomes and the power to get HE institutions to address student demands. In this context and central to making students into empowered consumers is cost-sharing, especially tuition fees and student loans, whereby a greater share of the costs of HE are borne by the main beneficiaries of HE-students and graduates-rather than by government and taxpayers, which is justified by the financial returns graduates reap. According to this argument, students will make more careful decisions about which institution and courses to enter if they have to pay for them and if they have better information on the outcomes of those possible choices. In turn, these student choices, when backed up with tuition fee payments and more provider competition, will force HE institutions to provide offerings that are more relevant to students and to the labour market because funding is now coming through students rather than directly from the government. Student choices will better accord with the needs of the labour market because the financial returns to different forms and levels of education will be a key factor students will weigh up in making their educational choices. This student-choice regime will expand HE, it is argued, if more students have greater access to financial support and if enrolment caps can be reduced or eliminated because government can limit its direct spending on HE. This student-choice regime will also increase equality of access if more working class students have access to financial support, enrolment caps have been lifted or eliminated, and institutions have an interest in attracting more students in order to make up for revenue they no longer receive from the government. Finally, it is argued, a student-choice regime will increase institutional quality if the total funds now available to HE institutions-both from student tuition and fees and direct public subventions (even if reduced)—exceed the total funding formerly available from the public purse (see Brown 2012, 2015, 2018; Naidoo et al. 2011).

Let us examine how this rationale for greater student choice and a more marketized HE system emerged in England focusing on the last two decades. We do this by examining the arguments advanced in commissioned reports, government white papers, and legislation, beginning with the 1997 Dearing Report. These documents were analyzed systematically, and key themes were identified through their close reading.

\subsection{The 1997 Dearing Report}

Policy rhetoric on student choice and provider competition emerges in the 1997 Dearing Report (NCIHE-National Committee of Inquiry into Higher Education 1997) which was tasked with making

"recommendations on how the purposes, shape, structure, size and funding of higher education, including support for students, should develop to meet the needs of the United Kingdom over the next 20 years". (NCIHE-National Committee of Inquiry into Higher Education 1997, p. 3) 
The Report's deliberations laid the foundations for England's current system of student choice and marketization of HE.

The Report argues that

"increasing participation in higher education is a necessary and desirable objective of national policy over the next 20 years. This must be accompanied by the objective of reducing the disparities in participation in higher education between groups and ensuring that higher education is responsive to the aspirations and distinctive abilities of individuals". (NCIHE-National Committee of Inquiry into Higher Education 1997, para. 7.1)

The Report notes how public policy had shifted in a neoliberal direction with a greater emphasis on market forces.

"There have been important changes since Robbins in the nature of the relationship between government and those who receive public funds. There have been moves towards the stronger interplay of market forces, in order to increase competition between providers and thereby encourage efficiency, and an emphasis on standards and accountability. These general trends have been reflected in higher education through the introduction of new funding methodologies, new approaches to quality assurance and an emerging focus on the 'consumer' rather than the 'provider'. Although the emphasis and the mechanisms may change over time, we expect there to be a continuing concern to promote efficiency, informed choice, quality and accountability over the next twenty years." (NCIHE-National Committee of Inquiry into Higher Education 1997, para. 4.39)

The Report develops a rationale for why student choice should drive institutional change in a more marketized system of HE. It contends "that student choice should be the main shaper of the system and that institutions must be enabled to respond flexibly" (NCIHE-National Committee of Inquiry into Higher Education 1997, para. 5.52). Additionally, student funding is to play a central role. In particular, the Report explores the pros and cons of "a 'block grant' approach for funding tuition and a system in which public funding flows to institutions on the basis of student choice" (NCIHE-National Committee of Inquiry into Higher Education 1997, para. 19.3). The Report rejects the idea of a 'block grant' approach because of its inflexibility and insensitivity to student demand. Instead, it supports a system in which public (or private) funds follow the student via tuition fees. For Dearing, the advantage of this approach is that funding flows to institutions based on student choice. Students' choices determine the shape of the system and institutions are encouraged to respond in order to maintain or increase recruitment and income. The Report claims that student choice will drive institutional responsiveness because "tuition contributions will enable students to be more demanding of institutions if they are making a direct contribution to the costs of their tuition" (NCIHE-National Committee of Inquiry into Higher Education 1997, para. 20.68).

The Dearing Report explores numerous options for how funding should follow the student, subscribing to the notion of cost-sharing. In the end, it opts for income-contingent loans to underwrite the introduction of tuition fees for full-time students and for their living costs. It believes "that a fair system of contributions from graduates in work should not represent a deterrent to participation in higher education" (NCIHE-National Committee of Inquiry into Higher Education 1997, para. 7.39), particularly for students from low socio-economic groups.

Despite the Report's support for lifelong learning, part-time students are treated quite differently. The report rejects providing part-time students with tuition fee loans, and grants or loans for living costs on the grounds that they would be prohibitively expensive (NCIHE-National Committee of Inquiry into Higher Education 1997). Instead, part-time students should rely on their wages or social security benefits to pay for their fees and maintenance up-front. The Report's key recommendation is improved support for those on social security benefits and access to a discretionary hardship fund. 


\subsection{The 1998 Labour Government Reforms}

On the day the Dearing Report was published in July 1997, David Blunkett, the then Education Secretary, announced the newly elected Labour government's proposals. They swept aside Dearing's recommendations for full-time students. Flat-rate tuition fees of $£ 1000$ per annum paid by all undergraduates and repaid via income contingent loans were replaced by means-tested fees of $£ 1000$ paid up front. The maximum private contribution to tuition fees was around one quarter of the average total cost of a course. Means-tested maintenance grants for living costs were traded for maintenance loans for all.

In making these reforms, Blunkett agreed with the Dearing Report's rationale for student choice and added that they would produce a beneficial impact on widening participation. When introducing the 1998 Teaching and Higher Education Act which implemented Labour's reforms, Blunkett declared that:

"The Act puts in place new funding arrangements for higher education designed to address the funding crisis we inherited. It modernises student support in higher education in a way that is fair to individual students and their families. Savings from the new arrangements will be used to improve quality, standards and opportunities for all in further and higher education". (DFEE 1998)

Elsewhere he comments:

"The new system of student support balances the contributions made by individuals and the community as a whole. It is more progressive than in the past, and it directs resources to those who need them most. Critically, it secures an income stream for higher education of fee contributions and loan repayments, which underpins expansion and the widening of opportunities". (Blunkett 2000, para. 70)

\subsection{The 2003 White Paper and the 2004 Higher Education Act}

The 2003 white paper (The Future of Higher Education) expands the legitimation of student choice to include meeting the needs of the economy and driving improved institutional efficiency and quality. The context is concern about competing in a globalized knowledge economy, harnessing knowledge for wealth creation, and meeting the high-level skills required in such an economy. ${ }^{1}$ HE has to expand to meet these rising skill needs and to widen participation to exploit "the talented and best from all backgrounds ... too many of those born into less advantaged families still see a university place as being beyond their reach, whatever their ability" (DfES Department for Education and Skills, p. 2). However, universities need "the freedoms and resources to compete on the world stage ... to undo the years of under-investment" (DfES Department for Education and Skills, p. 2). Universities' new freedom to set their own tuition fees (capped at £3000) "will allow them to fund their plans, and unleash their power to drive world-class research, innovative knowledge transfer, excellent teaching, high-quality, greater and more flexible provision, and fair access" (DfES Department for Education and Skills, p. 76).

The white paper also connects greater student choice to improving institutional efficiency in a more thorough going way than had previous policy reports. Openly using the language of the market, the white paper argues that "greater freedom and competition will compel institutions to improve their efficiency and management" (DfES Department for Education and Skills, para. 7.12). The report

1 The Labour government's concerns about meeting the demands of a knowledge economy were discussed in detail in a 1998 white paper, Our Competitive Future: Building the Knowledge Driven Economy (Department of Trade and Industry 1998). This white paper was much influenced by publications coming out of the World Bank on the nature of the knowledge economy, the importance of investment in higher education, and the need to substantially privatize it (Olssen and Peters 2005). 
argues that students, because they are sharing in the cost of their education, will operate more as consumers demanding good quality services:

“... in an era when students are being asked to contribute more to the costs of their tuition, to reflect the benefits it brings them, their expectations of teaching quality will rise. The Government believes that student choice will be an increasingly important driver of teaching quality, as students choose the good-quality courses that will bring them respected and valuable qualifications and give them the higher-level skills that they will need during their working life." (DfES Department for Education and Skills, para. 4.1)

Part-time students are recognized as an important constituency whose needs and desires should receive better response from institutions. The white paper argues for greater student choice in formats of study:

"Our system is not good enough at offering students real choice about how they learn. Higher education should be a choice open to everyone with the potential to benefit-including older people in the workforce who want to update their skills. There are not enough choices for flexible study-including part-time courses, sandwich courses, distance learning, and e-learning-and there must be an increasingly rich variety of subjects to study, which keep pace with changes in society and the economy." (DfES Department for Education and Skills, para. 1.27)

The 2004 Higher Education Act and various regulations that came into force in 2006 launched variable tuition fees for full-time courses, capped at $£ 3000$ a year, and repaid by graduates through income-contingent student loans, rather than 'mortgage style' loans previously available for maintenance. Consequently, all full-time students, even the poorest, had to pay tuition fees and all were automatically eligible for loans to cover all their fees. At the same time, the government introduced a package of financial support for low-income full-time students to safeguard access. This included the reintroduction, for full-time students only, of maintenance grants that Labour had abolished in 1998, the provision of bursaries funded by universities from their additional tuition fee income, and the establishment of the Office for Fair Access to regulate fees. To encourage more flexible study, tuition fee grants and course grants alongside access to a hardship fund were introduced for low-income part-time undergraduate students.

The 2004 Higher Education Act sought to use price to foster student choice and provider competition. It was hoped HE institutions would compete by charging different tuition fees for their courses and by offering discounts through bursaries and scholarships. The white paper argues that variable fees mean that "institutions will be able to reap rewards for offering courses that serve students well. It will make student choice a much more powerful force, and help choice drive quality" (DfES Department for Education and Skills, para. 7.28). In reality, such price competition never appeared. The $£ 3000$ top-up fee became a de facto flat rate, as eventually all universities charged the full $£ 3000$ a year for all their courses. Any competitive advantage of charging lower tuition fees was outweighed by the greater income derived from higher fees and by concerns over the reputational signals lower fees may send to potential students.

\subsection{The 2010 Browne Report}

The Independent Review of Higher Education Funding and Student Finance chaired by Lord Browne was launched in 2009 and reported in 2010. The Browne Report's case for reform focuses on three issues: increasing and widening HE participation; improving quality; and creating a sustainable solution for funding, especially reducing the sector's reliance on public funds (IRHEFSF (Independent Review of Higher Education Funding and Student Finance) 2010, p. 23). The Browne Report consolidated key elements of the evolving rationale for a HE finance and policy regime featuring student choice and marketization and it added new elements. 
With regard to consolidation, student cost-sharing is now treated as given: "The rationale for seeking private contributions to the cost of higher education is strong and widely accepted" (IRHEFSF (Independent Review of Higher Education Funding and Student Finance) 2010, p. 25). Additionally, given the constraints on public expenditure any "new investment will have to come from those who directly benefit from higher education" (IRHEFSF (Independent Review of Higher Education Funding and Student Finance) 2010, p. 25) namely, students. Moreover, the report reiterates the arguments that student choice will allow greater and wider participation and drive institutions to be more responsive both to students and the needs of the economy (IRHEFSF (Independent Review of Higher Education Funding and Student Finance) 2010).

Where the Browne Report breaks new ground in the legitimation of the neoliberal student choice model is in its call for sharply reducing direct government funding for $\mathrm{HE}$ and in the considerable attention it devotes to part-time students. The Report links enhanced student choice directly to student funding, with tuition fees and student loans having a pivotal role. In the Browne Report, block grants stifle growth and competition, and limit student choice, so funding must follow the student.

"What we recommend is a radical departure from the existing way in which HEIs are financed. Rather than the Government providing a block grant for teaching to HEIs, their finance now follows the student who has chosen and been admitted to study. Choice is in the hands of the student". (IRHEFSF (Independent Review of Higher Education Funding and Student Finance) 2010, p. 3)

The Report explains:

"Students will control a much larger proportion of the investment in higher education. They will decide where the funding should go; and institutions will compete to get it. As students will be paying more than in the current system, they will demand more in return". (IRHEFSF (Independent Review of Higher Education Funding and Student Finance) 2010, p. 29)

The Report, therefore, recommends that nearly all government funding to HE institutions should be withdrawn, and transferred to individual students via loans, to pay for higher tuition fees. Universities could charge whatever they like for their courses but those charging over $£ 6000$ would have to pay a levy to the government. HE institutions would compete for students based on price and quality, while theoretically, student choice would drive up quality and drive down prices through efficiency gains.

Browne's proposals also sought to develop a more diverse and flexible HE sector with more variety in the range and nature of HE provision. Essential to this was part-time study. The Report recommended that

"the same upfront support for the costs of learning is extended to part time students as well. Higher education will be free at the point of entry for all students, regardless of the mode of study, giving them more choice about how they choose to study-and where". (IRHEFSF (Independent Review of Higher Education Funding and Student Finance) 2010, p. 36)

Once again the Report invokes student choice and links it to improved higher education access:

"Part time students should be treated the same as full time students for the costs of learning. The current system requires part time students to pay upfront. This puts people off from studying part time and it stops innovation in courses that combine work and study. In our proposal the upfront costs for part time students will be eliminated, so that a wider range of people can access higher education in a way that is convenient for them." (IRHEFSF (Independent Review of Higher Education Funding and Student Finance) 2010, p. 5)

The Report, therefore, recommends the introduction of student loans for part-time students to cover their tuition fees. However, it rejects the idea of funding support for living costs, arguing that 
part-time students "are able to combine study with work; and they have access to other Government benefits in a way that full time students do not" (IRHEFSF (Independent Review of Higher Education Funding and Student Finance) 2010, p. 40)—arguments used in the Dearing Report.

\subsection{The 2011 White Paper and the 2012-2013 Reforms}

The Coalition government's response to the Browne Report, the 2011 White paper Higher Education: Students at the Heart of the System (BIS (Department for Business, Innovation and Skills) 2011) largely repeats Browne's thinking and objectives, as its title suggests. It seeks to make HE financially sustainable, improve the student experience, and increase social mobility within the framework of student choice and provider competition:

"Our reforms are designed to deliver a more responsive higher education sector in which funding follows the decisions of learners and successful institutions are freed to thrive; in which there is a new focus on the student experience and the quality of teaching and in which [there is] ... a diverse range of higher education provision. The overall goal is higher education that is more responsive to student choice, that provides a better student experience and that helps improve social mobility .... we want to ensure that the new student finance regime supports student choice, and that in turn student choice drives competition, including on price". (BIS (Department for Business, Innovation and Skills) 2011, p. 8)

The White paper confirms that most government funding to HE institutions would be withdrawn, and this lost income replaced by higher tuition fees repaid via loans:

"The public money that supports higher education courses should come predominantly in the form of loans to first-time undergraduate students, to take to the institution of their choice, rather than as grants distributed by a central funding council". (BIS (Department for Business, Innovation and Skills) 2011, p. 15)

However, contrary to the Browne Report's recommendations, tuition fees were to be capped at $£ 9000$ per annum for full-time courses and $£ 6500$ for part-time courses (obviating the need for a fee levy), but HE institution could charge whatever the market would bear up to these maxima.

Echoing the Browne Report, the White paper argued that "putting financial power into the hands of learners makes student choice meaningful" (BIS (Department for Business, Innovation and Skills) 2011, p. 5). More specifically, it claims "we want to ensure that the new student finance regime supports student choice, and that in turn student choice drives competition, including on price." (BIS (Department for Business, Innovation and Skills) 2011, p. 19).

A key part of the 2012-2013 reforms was the extension of tuition fee loans to part-time students, theoretically, making HE more affordable and accessible while enhancing student choice.

"For the first time, students starting part-time undergraduate courses in 2012/13, many of whom are from non-traditional backgrounds, will be entitled to an up-front loan to meet their tuition costs ... This is a major step in terms of opening up access to higher education, and remedies a long-standing injustice in support for adult learners." (BIS (Department for Business, Innovation and Skills) 2011, p. 61)

\subsection{The 2016 White Paper and the 2017 Higher Education and Research Act}

The 2016 white paper (Success as a Knowledge Economy) and the 2017 Higher Education and Research Act largely follow Browne in their arguments for a student choice and marketized HE policy regime. Student choice and the play of market forces are now seen as fundamental and taken for granted features of HE provision and policy. Student choice is legitimated on the now oft-stated grounds that it increases student access, widens participation, and drives greater institutional responsiveness to student desires and economic demands (BIS Department for Business, Innovation and Skills, p. 8). 
Where the White paper breaks new ground is in emphasizing that-for student choice to be effective-it must be backed up by adequate information and competitive institutions. These are not new arguments but they are given particular stress in this report. The White paper goes much further in its pursuit of creating a competitive market and choice for students. It pronounces that "insufficient competition and a lack of informed choice" (BIS Department for Business, Innovation and Skills, p. 8) mean HE is not fulfilling "its potential as an engine of social mobility, a driver of economic growth and cornerstone of our cultural landscape" (BIS Department for Business, Innovation and Skills, p. 8). With regard to informed choice, the White paper states:

"For competition in the HE sector to deliver the best possible outcomes, students must be able to make informed choices ... information, particularly on price and quality, is critical if the higher education market is to perform properly. Without it, providers cannot fully and accurately advertise their offerings, and students cannot make informed decisions ... With better information, students will be able to make informed choices about their higher education options and their future careers." (BIS Department for Business, Innovation and Skills, pp. 11-12)

In addition, providers must be prodded to become more competitive:

“By introducing more competition and informed choice into higher education, we will deliver better outcomes and value for students, employers and the taxpayers who underwrite the system. Competition between providers in any market incentivizes them to raise their game, offering consumers a greater choice of more innovative and better quality products and services at lower cost. Higher education is no exception." (BIS Department for Business, Innovation and Skills, p. 8)

These emphases are reflected in the 2017 Higher Education and Research Act. A key purpose of the Act is to establish a regulatory "architecture" to create a HE market where competition and choice flourish. The main change enacted is the creation of the Office for Students (OfS), a new regulator and funding council for universities which has a statutory duty to promote choice and competition. OfS will "champion" students and widening participation (incorporating the functions of the Office for Fair Access), hold the statutory responsibility for quality and standards, approve new entrants and the awarding of university title and degree awarding powers. It will oversee the Teaching and Excellence Framework (TEF) aimed at raising the quality and status of teaching in HE institutions. ${ }^{2}$

Finally, choice and competition have informed the remit of the Review of Post-18 Education and Funding set up by the government in 2018 to

"ensure that the education system for those aged 18 years and over is accessible to all, is supported by a funding system that provides value for money and works for students and taxpayers, incentivizes choice and competition across the sector, and encourages the development of the skills that we need". (DfE 2018a)

The Review will report late 2018 or early 2019.

The rationale for student choice and marketization, underpinned by student funding reforms, that developed over the two decades following the Dearing Report, has involved certain key claims that can be evaluated. The move toward greater student choice and the greater play of market forces was forecasted to produce greater access to HE by both full time and part-time students, wider participation by students of different backgrounds, improved institutional quality, and greater HE responsiveness to the labour market. These changes were to be driven by two key mechanisms: High

2 When TEF was first introduced, it was anticipated that successful TEF performance would be linked to the level of tuition fees higher education institutions could charge. But this idea been deferred until 2020, in the hope that the evaluative procedures will command greater confidence by then. 
levels of student participation in student loan programs and a greater range of provision by $\mathrm{HE}$ institutions. Has this happened? Has this idealization of choice been an illusion? This question is taken up in the next section of this paper.

\section{Assessment of Proponents' Claims About The Benefits of Student Choice}

There are numerous policy predictions underpinning the student-choice and marketization model as it emerged in the commissioned reports, white papers, and legislation we examined above. These include: The expansion of HE and widening participation; improvements in the quality of provision; a system more responsive to the needs of the labour market; and greater variety in provision, especially more flexible provision. In this section we examine how well those predictions were met, especially since 2010/11, the last year unaffected by the 2012 reforms. Did the idealizations of student choice that we examined in the previous section turn out to be illusory?

\subsection{Increasing and Widening Higher Education Participation}

The total number of UK and EU undergraduate entrants to English HE institutions and Further Education (FE) colleges fell by 14 per cent between 2002/3 and 2016/17, and by 21 percent between 2010/11 and 2016/7, contrary to the assumptions underpinning the student-choice model (Figure 1). The decline has been driven largely by drops among part-time entrants. Part-time entrant numbers peaked in 2003 and again 2007 but then declined year on year, and fell dramatically as a result of the 2012/13 student funding reforms. In 2010/11, there were 259,000 entrants. By 2016/7, the numbers had plummeted to 100,000 - a fall of 61 per cent. The falls at the Open University (OU) were even greater than those at other universities and Further Education (FE) colleges. By contrast, full-time numbers have risen continuously since 2002/03, except for temporary dips associated with tuition fee increases, after which numbers subsequently recovered and rose year on year. Between 2010/11 and 2016/7, the number of full-time entrants grew by six-percent despite the demographic downturn in the number of 18 year olds over this period. The rise in full time numbers and falls in part-time numbers meant that, by 2016/17, only around 20 percent of all undergraduates studied part-time compared to 46 percent in $2002 / 3$.

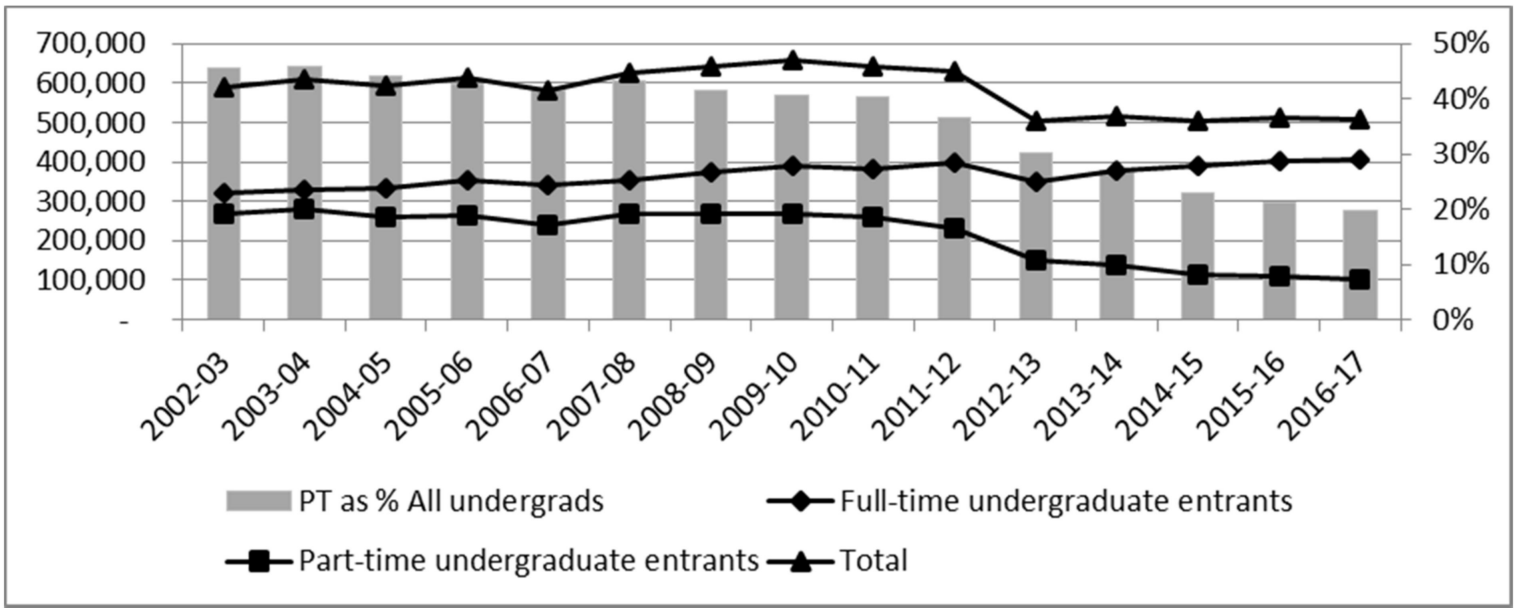

Figure 1. UK and other EU entrants to English HE Institutions and FE Colleges, 2002-2003 to 2016-2017. Source: Derived from HEFCE $(2015,2018)$.

These figures clearly show that HE has not expanded in line with the predictions of the student-choice model, nor has flexible provision grown. Access to HE has been curtailed while student choice constrained, especially access to part-time study. And the greater fall in entrants to the Open University compared with other universities and FE colleges, also suggests that access to distance 
learning courses has been affected more than face to face part-time provision at other universities and FE colleges.

Another promise of the student-choice model is that HE participation would widen and there would be more opportunities for groups currently under-represented to enter HE. At first blush, the evidence is promising. Between 2010/11 and 2015/16, the largest proportionate increases were among those from the most educationally disadvantaged areas. They saw an increase of 28 percent compared with a five per cent increase among those from the most educationally advantaged areas (HEFCE 2016). However, a different and more mixed picture emerges when we disaggregate the data. Widened participation has been achieved but only among those aged 20 and under who study full-time. Among all part-time students, the numbers have fallen.

Data from UK Performance Indicators on Widening Participation (HESA 2018a, 2011a), show that between 2010/11 and 2015/16, the percentage of English domiciled disadvantaged full-time entrants from low participation neighbourhoods (POLAR3) rose by 13 percent, and for young (aged 20 and under) entrants by 18 percent. However, the numbers for mature full-time entrants fell by two per cent. Moreover, the percentage of all part-time undergraduates entrants from low participation neighbourhoods (POLAR3) fell by 58 per cent, among young part-time entrants by 60 per cent, and among mature entrants by 57 per cent (derived from HESA 2018a, 2011a). The falls among part-timers are extremely significant for a group that need greater access to HE. Moreover, the decline in disadvantaged part-timers partially offsets the trumpeted increases in disadvantaged HE participation at the full-time level.

'Widening participation' students continue to form a small proportion of all undergraduates and little progress has been made in increasing their share (Boliver 2011). Young full time entrants from low participation areas formed just 10.4 per cent of all young full-time entrants in 2010/11 and 11 per cent in 2015/2016 (HESA 2018a, 2011a). By comparison, the share of entrants from the highest participation areas was much higher at 30 per cent in 2015/16 (HEFCE 2016). Mature full-time students from low participation areas made up just 11.3 per cent of all mature full-time entrants in 2010 and 12 per cent in 2015. Young part-time entrants living in low participation areas formed 12.8 per cent of all young part-time entrants in 2010 and 14.8 per cent in 2015. Mature part-time students from low participation areas made up eight per cent of all mature full-time undergraduate entrants both in 2010 and 2015 (derived from HESA 2018a, 2011a).

The student-choice model not only aims to increase and widen participation but also ensure that more disadvantaged students enter the most prestigious universities. Indeed recent government documents are more preoccupied with this, than widening access more generally. However, little progress has been made (Boliver 2015). The most prestigious universities and courses in England and in the world, remain dominated by students from the most privileged family backgrounds (Marginson 2016b). In England by 2015-2016, 41 per cent of undergraduate entrants to high status universities—-those with high entry tariffs—came from the most advantaged areas, whereas only 6.6 per cent came from the most disadvantaged areas (HEFCE 2016).

The most accessible UK trend data on these disparities are produced by Universities and Colleges Admissions Service (UCAS) but for young full-time students only. ${ }^{3}$ Using a variety of measures, the UCAS data clearly show that there has been no substantive change in the proportion of young people from the most disadvantaged backgrounds attending the most prestigious universities, and this has been the case for the past three decades (Boliver 2011). For instance, using the multiple equity measure that aims to capture the multidimensional nature of disadvantage, the entry rate for the most

3 This data source is severely limited. First, it only collects data on applications and acceptances to higher education which is different from the actual number of entrants (but it does calculate entry rates). Secondly, it excludes potential part-time students because they do not apply to higher education institutions through UCAS but directly to institutions. Finally, the measures of social disadvantage used primarily apply to young people and consequently the analysis focuses just on young students, especially 18 year olds rather than all full-time students. 
disadvantaged 18 year olds into high tariff institutions was 1.5 per cent in 2010, and by 2017 had risen just one percentage point to 2.5 per cent. However, entry rates for the most advantaged rose at a faster rate from 21 per cent in 2010 to 24 per cent in 2017. So by 2017, those young people who are most likely to go to university were nearly ten times more likely to enter a higher tariff university than those who were least likely to enter HE (UCAS 2017 derived from Figure 5.3). Most lower income pupils enter low tariff, low status and less well-resourced HE institutions.

So HE for young people remains highly stratified, despite the expansion of full-time undergraduate HE. As Marginson (2016a, p. 421) observes, prior social inequalities determine whether those from low income families can improve their social circumstances while "higher education provides a stratified structure of opportunity" with students from affluent families dominating "high value positions within higher education." Full-time HE expansion has not reduced class inequalities in access to elite HE (Arum et al. 2007), and in fact, may exacerbate these inequalities (Marginson 2016a, 2016b; Stich and Freie 2016).

\subsection{Enhanced Institutional Quality}

Central to the student-choice model is improvements in the quality of provision. The argument is that choice induces pressure on HE institutions in their competitive struggle for students, which has become more intense since 2015 when the cap on student numbers was lifted. If students value quality provision and have the information to recognise it, and if HE institutions benefit and expand with greater demand, then the market should operate to raise their quality. Poor-quality institutions will lose students and funding and so work to reverse this by raising their performance.

The challenge with assessing quality and the influence, if at all, of greater student choice on quality is the lack of consensus as to what constitutes 'quality'. As Ashwin et al. (2013, p. 2) observe, "whilst marketization has led to an increased focus on the quality of undergraduate education, it does not define the meaning of quality because markets are reliant on definitions from elsewhere." They continue "The literature on quality in HE has indicated a struggle between a marketized, consumerised definition of the quality of HE being about fitness for purpose and value for money and definitions of quality that are based on the transformation of students" (Ashwin et al. 2013, p. 2). However, even within the consumerized definition, there is continuing debate about what constitutes teaching excellence (Gibbs 2012; Gunn and Fisk 2013); As a result, there is no consensus on what should, and can be, measured to assess quality. Indeed, some argue that there are no robust and reliable measures-a long-standing issue in England and elsewhere (Blackmore et al. 2016; Hazelkorn et al. 2018; Land and Gordon 2013). Consequently, it is impossible to conclude that institutions' quality has improved, remain unchanged, or deteriorated as a result of the student-choice cost-sharing.

In the Teaching Excellence and Student Outcomes Framework (TEF), a national exercise in England aimed at enhancing student choice and provider competition, proxy measures are used to assess quality (OfS 2018a). What is measured really matters, and the initial TEF phase has been criticised because the proxy measures (student satisfaction with teaching quality; completion rates and employment outcomes) fail to capture what many argue is the 'un-capturable' essence of teaching quality. These metrics are only outcome based, ignoring for instance, inputs ${ }^{4}$ and processes ${ }^{5}$ Others have criticised TEF because it is based on the idea of students as passive recipients of knowledge, ignoring all the research demonstrating the co-production of knowledge (Barnett 2013).

4 These might include staff teaching qualifications, staff research expertise or industrial and business experience, research-informed teaching, and activities and resources to support learning such as investment in specialist equipment, technology and facilities.

5 These might include curriculum design, development and review, student assessment and feedback, optimisation of retention and progression, industrial engagement and volunteering opportunities, and student partnerships. 
However, one metric used in the TEF, derived from the National Student Survey (NSS), could be seen as explicitly measuring quality. ${ }^{6}$ The Survey asks all final year undergraduates the following question: "Overall, I am satisfied with the quality of the course". When the NSS started in 2005, 80 percent of full-time students in England were satisfied, ${ }^{7}$ rising to 81 per cent in 2010, peaking at 85 per cent in 2013, and then falling to 83 per cent by 2017. The equivalent figures for part time students were 87 per cent in 2010 and then falling to 85 per cent by 2018. Interestingly, scores tend to be higher in Scotland, where students do not pay tuition fees (HEFCE 2014a; OfS 2018b). Taken together, these NSS scores show how satisfaction with quality has been falling slightly in recent years, coinciding with the student-choice model reaching a new height with the introduction of tuition fees of $£ 9000$. Moreover, the overall TEF results, of which these NSS scores form a part, have been inconclusive to date. A mix of high and low status HE institutions were awarded the highest (gold) and lowest (bronze) ratings with no obvious pattern to the awards-'excellence' is distributed across the sector and matches its diversity.

\subsection{Improved Labour Market Responsiveness}

Another purported impact of the student-choice model, is an improvement in graduate employment outcomes. Theoretically, the gap between the skills taught by the HE system and what employers need is closed, as students choose subjects and courses with better employment prospects. There are several problems with this assumption. First, HE has little or no influence over the operation of the labour market and its fluctuations, and hence on their graduates' employment opportunities. Yet this is assumed in the choice model. Second, as higher education participation rates have risen, so have the number of graduates (LFS Labour Force Survey) and consequently, getting a degree may no longer be adequate for securing a well-paid 'graduate' job (Brown 2013). Thirdly, the graduate job market, and indeed the economy as a whole, is changing rapidly due to a number of technological and political factors. Consequently, past graduate behaviour and experiences, such as their earnings, are not indicators of say, future graduate earnings. Yet information on graduates' labour market experiences perforce relies on historic data.

The Destinations of Leavers from Higher Education (DLHE) survey, provides key data on graduates' initial labour market experiences for those graduating from a HE institution in England. But these data only cover the period six months after graduation, which is a major limitation as it takes time for graduates to settle into their careers. ${ }^{8}$ In 2008/09 (the first cohort of graduates who had paid fees of $£ 6000$ ), among those graduating with a first full-time degree, 59 per cent were employed; 26 per cent were in further study or both working and studying; 10 per cent were unemployed, and the remaining categorised as 'other' (HESA 2011b, Table 1a). Their median salary (to the nearest $£ 500$ ) was $£ 20,000$ but ranged from $£ 15,000$ among the lower quartile to $£ 23,000$ in the upper quartile (HESA 2011b, see Table 5). By contrast, those graduating from part-time study with a first degree had higher employment levels and earnings. Some 65 per cent were employed; 21 per cent were in further study or both working and studying; 6 per cent were unemployed; and the remaining categorised as 'other' (HESA 2011b, Table 2a). Their median salary was $£ 25,000$ but ranged from $£ 20,000$ among the lower quartile to $£ 32,000$ in the upper quartile (HESA 2011b, Table 5).

In 2015/16 (the first cohort of graduates who had paid fees of $£ 9000$ ), the equivalent figures for graduates of full-time study were 67 per cent in employment; 22 per cent both in work and study or only in further study; 6 per cent were unemployed; and the remaining categorised as 'other' (HESA 2017, Table 4b). Their median salary was $£ 21,000$ but ranged from $£ 17,000$ among

6 However, many criticise the NSS for measuring satisfaction rather than quality. See Ramsden and Callender (2014) for a review of the literature.

7 Part-time students were only included in the survey later.

8 There are other limitations to the DLHE and many of these are being addressed in the new Graduate Outcomes survey which will replace the DLHE. 
the lower quartile to $£ 25,000$ in the upper quartile (HESA 2017, Table 10). In 2015/16, among part-time first degree leavers, 72 per cent were employed; 14 per cent were both working and studying or in further study only; 5 percent were unemployed; and the remaining categorised as 'other' (HESA 2017, Table 5b).

From these data, it appears that labour market outcomes have improved during the period of the expansion of student choice. Arguably, part-time study is more responsive than full-time study to employers' needs. This is unsurprising as most part-time students are mature and work while studying and are not new labour market entrants.

It is unclear, however, how much these changes can be attributed to the expansion of student choice. As suggested, graduates' employment opportunities are shaped by the state of the economy. The lower proportion of graduates from full-time study who were employed in 2008/09 compared with $2015 / 16$ is largely attributable to the fact that they entered the labour market during the recession-a finding confirmed by other data, which show graduate unemployment peaking in 2009 and in 2011, and then falling (LFS Labour Force Survey).

These data give no indication of the type of jobs graduates are gaining and if they are 'graduate jobs'. While definitions of what is meant by a graduate job vary (Elias and Purcell 2013; Green and Henseke 2016), the Labour Force Survey data divides jobs into graduate and non-graduate jobs with the latter defined as a job which does not require a HE background. The percentage of recent ${ }^{9}$ full-time graduates who were working in a non-graduate job rose from 41 per cent in the July to September quarter of 2002, to 46 per cent in the same quarter in 2010, and to $49 \%$ in 2017 (LFS Labour Force Survey, Figure 8). ${ }^{10}$ This growth in underemployment may reflect lower demand for graduate skills as well as an increased supply of graduates.

A key limitation of the DHLE data is that they are based on graduates' experiences just six months after graduation. The new Longitudinal Employment Outcomes (LEO) survey provides a longer view on graduate outcomes and more accurate data on their earnings. ${ }^{11}$ For instance, published LEO data includes information on the labour market experiences of students who graduated in 2008/09 (the first cohort subject to fees of $£ 6000$ ) one, three, and five years after graduation disaggregated by a range of variables (DfE 2018b). However, comparable data for those who graduated in 2015/16 or later are not yet in the public domain. Consequently, it is not possible to use the LEO data to assess any changes in graduate outcomes associated with the period of expansion of student choice.

However, analysis of LEO data provides some important insights into inequalities in the graduate labour market. Using LEO data for graduates of full-time study only, Britton et al. (2016) showed how graduate earnings vary enormously not only by subject of study and the prestige of the HE institution attended (in large part driven by differences in entry requirements), but also by gender, ethnicity, and parental income. For instance, graduates' family background and whether they come from a low or high-income household continues to influence graduates' earnings over a decade after graduation, even when they experience the same higher education. After taking into account "different student characteristics, degree subject and institution attended, the gap between graduates from higher and lower income households is still sizeable, at around 10\% at the median" (Britton et al. 2016, p. 55).

Taken together, these results tell us little about the overall effectiveness of the student-choice model. Graduate employment and unemployment levels have fluctuated primarily because of the state of the economy while for the same reason new graduates earnings' have fallen in real terms. Data on the underemployment of graduates suggests that to date, the choice model is not delivering its promises. Other evidence shows increasing dispersion in the returns to tertiary education (Green and Henseke 2016). Moreover, that graduates' family background determines their earnings

9 Defined as having left full time education within five years of the survey date.

10 Because the classifier is fixed for the whole period, it may miss within-occupation upskilling and thus overstate the rise of underemployment. See Green and Henseke (2016).

11 It provides no data on graduates' occupation, giving only a partial picture of graduate outcomes. 
long after graduation suggests that factors outside the control of universities and student choices continue to influence graduate earnings. Clearly, widening access for low income students may not provide social mobility, especially if access among high income students rises as much or more. It is highly questionable whether students in future will change their HE choices in the light of LEO data and whether they should - as policymakers hope. There is more to HE than its financial returns, yet the student-choice model primarily measures labour market responsiveness in terms of graduate earnings.

\subsection{Greater Variety of Provision}

Central to the choice agenda is the idea that there should be greater diversity in provision so that students can choose how and what to study. But that is not what has happened. All HE institutions have tended to converge in their offerings because they are similarly pursuing the same standard of excellence and prestige as defined by the commercial league tables and other assessors and because the risks of standing out are too great (Brown 2018).

The part-time sector is not just smaller as a result of the 2012 reforms, but it is also different. The nature, breadth and flexibility of part-time provision have changed because of the funding reforms curtailing student choices. First, there has been a dramatic shift in part-time entrants' qualification aims and second in their intensity of study. Between 2010 and 2015, the number of non-degree ${ }^{12}$ entrants to UK universities and FE colleges in England declined more rapidly than degree entrants (57\% compared with $33 \%$ ), and especially at the OU ( $88 \%$ non-degree compared with $31 \%$ degree). Typically, these non-degree courses are more vocationally orientated than degree courses, and traditionally have been highly responsive to employers' needs. Moreover their severe decline points to the homogenisation of the HE provision. Concurrently, there was a 64 per cent decline in the total number of entrants studying on courses of less than 25 per cent intensity, driven by a fall of 94 per cent at the OU, compared with a fall of 46 per cent at other UK universities and FE colleges (Callender and Thompson 2018). These changes suggest that students are no longer taking these short courses because they do not attract loan support, while HE institutions are modifying their provision so more potential students can qualify for loans. So despite the Browne Report and the 2011 White Paper's calls for more diverse and flexible provision, these trends suggest there is now narrower provision. Fewer people will be able to "access higher education in a way that is convenient to them" (IRHEFSF (Independent Review of Higher Education Funding and Student Finance) 2010, p. 5).

These shifts, and the overall decline in part-time study, are associated with the most significant mechanism for delivering the choice agenda-student loans which act as a voucher that students can redeem at the institution of their choice. However, far fewer part-time students turned out to be eligible for loans than the government anticipated. We pick up this point in the next part of the paper.

\section{A Critique of The Student-Choice Concept as Elaborated by Policy Makers}

As we have seen above, the student-choice and marketization model that has evolved over the last three decades in England has only partially met its expectations. Enrolments have declined since 2010, particularly among part-time students. Participation has widened among low-income students but this impact has held only for those who are under 20 years of age and attending full-time. And in any case, the social-class composition of HE students-both as a whole and among those in high-tariff universities-has changed very little. There is limited evidence that labour market responsiveness or institutional quality have improved, and some evidence that both have deteriorated. Additionally, the variety of offerings available to students, particularly part-time students, has actually declined.

12 Non-degree qualifications include: Foundation Degrees (FD), HND and HNC: Other higher education qualifications, for example Certificate of Higher Education; and Institutional Credits—credits that can be aggregated to qualify for a higher education award but which do not constitute an award in their own right. 
How do we explain these anomalies? We argue that much of this is due to misconceptions that were woven into the student-choice model and the policies that were adopted in its stead.

\subsection{Explaining the Decline in Enrolments, Especially Among Part-Time Students}

Most immediately, the government did not anticipate that most institutions would move to charging $£ 9000$ for their full-time courses, and they had no contingency if that proved to be the case. Moreover, the officials did not foresee the high degree to which part-time students were ineligible for loans or would find the loan terms onerous.

\subsubsection{The Sharp Rise in Tuition Fees}

The first immediate effect of the 2012 reforms, unsurprisingly, was a steep rise in tuition fees because HE institutions no longer received direct public funding for most of their teaching. Across the sector, fee increases were greater than anything experienced before, and in most cases triple their pre-2012/13 level.

Apparently the government did not expect that all universities would charge the maximum $£ 9000$ for all their full-time courses. It was assumed that only in exceptional cases would $£ 9000$ be charged. For example, then Minister for Universities and Science David Willetts stated: "We are in a system where there will be a continuing and very important role for the Government, through providing financial support and through the new regulatory regime that emerges as we think through the proposals from Lord Browne, and where there is a very clear cap-a threshold of $£ 6000$, and in exceptional circumstances, up to $£ 9000 "$ (House of Commons 2010). Moreover, there were no contingency plans if this did not turn out to be the case and virtually all institutions went to $£ 9000$, undermining price as a choice mechanism.

However, there was more variability in part-time fees, within the maximum of $£ 6500$. For university part-time degree courses, the median in 2012 was $£ 5000$ per FTE (HEFCE 2014b) but some institutions charged the same as the full-time maximum, or $£ 9000$ per full-time equivalent (Thompson and Bekhradnia 2013, p. 8; Callender 2013, p. 145).

These 2012 fee increases significantly accelerated the decline in part-time entrants. By comparing trends for entrants domiciled in England, with those in Scotland and Wales, who were unaffected by the 2012 reforms, the impact of higher tuition fees can be isolated. Open University (OU) data provides the most convincing evidence because it offers broadly the same courses to students living in England, Scotland, and Wales. Over time, the fees charged in these three countries for the same or very similar courses have diverged because of different funding policies. Between 2007 and 2011, when the fees were the same for entrants in England, Scotland and Wales the trends in part-time entrants to the OU were similar. Between 2011 and 2012, students in England saw a real increase in fees of 247 per cent, compared to two per cent for those from Scotland and Wales. By 2012, the number of entrants living in England had declined 43 per cent compared to 2010 despite the introduction of fee loans, whereas in Scotland and Wales there was little change. Since 2012, a further decline in England has been matched by falls in Scotland and Wales but the falls were much larger in England. From this analysis, it is clear that the 2012 fee increases significantly exacerbated the long-term decline in part-time entrants in England (Callender and Thompson 2018).

Trends in entrants in England and Wales to universities (excluding the OU) and FE colleges also suggest that if the numbers in England had declined by the same proportion as those living in Wales, in 2015 there would have been 149,000 part-time students instead of 106,000. This suggests that something like 40 per cent of the decline in English domiciled entrants can be attributed to the 2012 reforms, with over 43,000 fewer entrants in 2015 than would be expected without those changes (Callender and Thompson 2018).

The sharp rise in tuition may not have been a problem if-as in the case of full-time students-student financial support in the form of fee and maintenance loans and grants were made widely available. But this did not happen in the case of part-time students. 


\subsubsection{Difficulty of Part-Timers in Getting Loans}

The new loans for part-timers introduced in 2012 were designed to protect students from tuition fee rises, to make part-time study more affordable, and to safeguard access. However, far fewer part-time students turned out to be eligible for loans than the government anticipated because of the loans eligibility criteria and repayment terms.

Students who want or need a loan have to commit to undertaking a degree at the outset of their study because of the loan eligibility criteria. They can no longer gain a degree by building up institutional credits over a number of years and coming in and out of study. Nor can students get loans for short courses of less than one year because of the loan eligibility criteria. To get a loan, a student must study at intensity greater than 25 per cent of a full-time equivalent course. Additionally, they have to aim for a qualification that is not at an equivalent or at a lower level than any qualification (ELQ) they already hold. For example, if a student already has a Bachelor's degree, they cannot get a loan to pay for a second Bachelor's degree. As a result, by 2015, only $47 \%$ of all part-time entrants to UK universities and FE colleges in England were eligible for a loan. Some 81 per cent of OU entrants were eligible, but only 35 per cent of part-time entrants to other UK universities and FE colleges were eligible, suggesting that the OU modified their provision so more potential student would be eligible for loans (Callender and Thompson 2018).

Consequently, excluding OU entrants, around two-thirds of part-time entrants do not qualify for loans because of the restrictive eligibility criteria. They have to pay their higher tuition fees up-front, out of their pocket, or abandon the idea of studying, making a mockery of the Browne Report's declaration that: "Higher education will be free at the point of entry for all students, regardless of the mode of study, giving them more choice about how they choose to study-and where" (IRHEFSF (Independent Review of Higher Education Funding and Student Finance) 2010, p. 36). Additionally, as research in the UK and elsewhere, repeatedly shows, upfront fees and fee increases have an adverse impact on participation unless they are accompanied by equivalent increases in student financial support (Dearden et al. 2010, 2014; Dynarski 2003).

But even when part-time students are eligible for loans, many of them do not take them out. Of those eligible for tuition loans, only 59\% of part-timers took them out in 2012 (Callender and Thompson 2018), compared with over $89 \%$ of full-timers (Bolton 2018). A contributing factor is that the loan-repayment terms are more onerous for part-timers. Part-time students must begin to repay their loans, at the latest, in the April four years after they start their course, even if they are still studying. As part-time Bachelor degree courses typically last 5-6 years, and the majority are in paid work while studying and earning above the loan repayment threshold (see graduate earnings data above), most part-time students studying for a Bachelor's degree will have to start repaying their loan before reaping any financial benefits of their study. By contrast, full time students do not have to begin to repay their loans until the April after they leave their course. As a result, many part-time students are reluctant-even if eligible- to take out loans.

But the deficiencies in the government's student financial support scheme go even deeper. Its very conceptualization of who students are and how they make HE decisions is deeply flawed. These more fundamental deficiencies not only help explain the collapse in part-time enrolments but also help explain why-despite the great increase in HE full-time participation over the last two decades-the social-class gap in participation has barely budged. Within HE, there has been a growing divergence in social class distribution across top-rank as versus bottom-rank institutions (Callender and Mason 2017, pp. 23-24; House of Commons, Committee of Public Accounts 2018, p. 10; Murphy et al. 2017, pp. 27-32; National Audit Office 2017). ${ }^{13}$

13 While noting this, it is important to keep in mind that the main determinant of social-class differences in access to higher education is differentials in academic preparation (Vignoles and Crawford 2010). 


\subsection{Explaining the Lack of Reduction in Class Inequality in Access}

The student-choice model used by the higher education policymakers embodied several misconceptions that help explain why class differences in rates of access to HE in general and to high-tariff institutions in particular have changed very little. Government policymakers had a simplistic view of students that insufficiently acknowledged their varied characteristics, social standpoints and attitudes toward debt. Moreover, the officials incorrectly assumed that the main choice variables students would weigh are the costs and economic benefits of particular university programs when in fact students weigh many other factors as well (Brown 2012; Perna 2006; Reay et al. 2005).

\subsubsection{Insufficient Acknowledgement of Students' Varying Attitudes toward Debt}

HE policymakers neglected to take into account the differences among students, especially in their attitudes toward taking on debt. Rather, they adopted a 'one size fits' all approach to policy. There was an unconscious assumption that students are young, single, middle, and upper class school-leavers and first-time entrants into the labour market who are comfortable taking on large debt because their families are familiar with debt-based investments and they anticipate getting jobs that will allow them to pay off their educational debts. Moreover, it is assumed that because student loans are income-contingent and not like other debts, students will not be debt averse. However, these assumptions are incorrect for part-time students and do not work well for working-class students more generally.

As government research confirms, part-time students are far more price sensitive and debt averse than their younger full-time peers, probably because they are older, have families, and already have financial commitments such as mortgages (Callender and Thompson 2018). Taking out a student loan and having to pay, in reality, an additional nine per cent in marginal tax to repay their loan, or more than $£ 6000$ a year for fees, is a leap of faith when the returns on their investment are variable and uncertain. The financial returns from lifelong learning, in terms of higher earnings and improved employment opportunities, are decidedly mixed (Dorsett et al. 2010). As the data on graduate experiences above show (see Section 3.3), the early employment outcomes and earnings for graduates of part-time study tend to be better than for full-time graduates because they are older, have more work experience, and are not new labour market entrants. However, other data five years after graduation show that part-time graduates' salaries grow at a slower pace and are more likely to stagnate compared with those of their full-time peers (DfE 2018b). Consequently, there are potential financial 'risks' associated with part-time study, especially for those taking out a loan, who may not get higher salaries to cover the additional costs of loan repayments.

These points hold as well for working-class students more generally who are especially reliant on student loans if they want to study (Pollard et al. 2013). ${ }^{14}$ Many working-class students are concerned about their ability to pay off loans and have negative attitudes-often based on painful family experience - toward taking on debt (Callender and Mason 2017; Jones 2016; Perna 2008; see also Dynarski and Scott-Clayton 2013; Goldthorpe 1996). As the data on graduate employment and earnings discussed above highlight (see Section 3.3), the financial returns from HE vary considerably by student characteristics, the subjects they study, the universities they attend, and their social class, with the dispersion between top and bottom earners growing over time (Dearden et al. 2012; Green and Zhu 2010; see also Scott-Clayton 2016). This makes HE a risky investment (Jones 2016). These factors help explain Callender and Mason's (2017) findings concerning the role of debt aversion in affecting $\mathrm{HE}$ applications by young working-class students. Analysing a nationally representative survey of students in England who were studying toward HE entry qualifications, they found that prospective students from working-class backgrounds were significantly more likely to hold negative

14 In 2015/16, an estimated 89.5 per cent of English undergraduate students took out maintenance loans and 94 per cent of students took out tuition loans (Student Loans Company 2017). 
attitudes toward taking on debt. Moreover, those attitudes were significantly predictive of lower intentions to enrol in HE, even when controlling for gender, race, age, GSCE test results, and type of secondary school attended (Callender and Mason 2017).

Concerns about debt can also affect choice of institutions (Mangan et al. 2010). Based on a survey of student applicants in 2007, Mangan et al. (2010) found that not having debt concerns was significantly predictive of applying to Oxbridge, even after controlling for family background, location, type of secondary school, and examination performance.

\subsubsection{A Narrow Conceptualization of Student Choice Making}

The inattention of the government officials to differences in students' attitudes toward debt is related to another problem: the officials' narrow view of how students go about making HE decisions. Policy makers have largely followed the human-capital model that has dominated US discussions of student choice (Perna 2006). Students are conceptualized as rational calculators primarily weighing the costs and benefits of HE and the relative quality of institutions and programs. There is little awareness of the fact that student choices are shaped by several other factors as well-including psychological traits (including use of heuristics and cognitive shortcuts), aspirations, socio-psychological identities, and emotional responses-and that these vary considerably by social background (Callender and Jackson 2005; Devine 2004; Diamond et al. 2012, 2014; Dougherty 2018; Jones 2016; Lareau and Cox 2011; Perna 2006; Reay et al. 2005).

Drawing on Pierre Bourdieu's concept of habitus (Bourdieu 1977, 1984), Diane Reay and her colleagues have argued: "Choices are bounded by the framework of opportunities and constraints the person finds herself in, her external circumstances ... She is also circumscribed by an internalised framework which makes some possibilities inconceivable, others impossible and a limited range acceptable" (Reay et al. 2005, p. 27).

We have touched above on one key dimension of habitus: attitudes toward risk, ${ }^{15}$ whether taking on debt or taking other chances. Students not only weigh costs and benefits but also risks, and calculations of risk can be quite different by social class, race, and age. Particularly for working-class students, risks are not only economic, such as the risk of taking on loans that one might not be able to pay off, but also academic and cultural.

Many working class and non-white students perceive a considerable risk that they may fail to succeed academically at university or even drop out (Archer et al. 2002; Reay 2001, 2005). They fear that they may be academically unprepared or hold qualifications HE institutions do not respect or they may have to compete with middle and upper-class students who are much better prepared. Mature and part-time students face similar fears and encounter the additional challenge of juggling their work and domestic responsibilities with their studies, which contribute to much higher non-completion rates compared to their younger full-time peers (HESA 2018b).

Furthermore, many students fear that HE institutions will not be receptive to students of their background and subject them to discrimination and other forms of ill treatment. A significant number of Black and minority ethnic students express concerns that at very white institutions they will be marked out as different and encounter discrimination from teachers and students (Archer et al. 2002; Read et al. 2003). Many working class students "undermatch" by picking institutions less selective than they are capable of because they fear that higher prestige institutions will be "snobbish" and they will not fit in (Read et al. 2003; Reay 2001; see also Mullen 2010). Finally, many mature students are uncomfortable with institutions that seem focused on younger students, fearing that they will be inattentive to the needs of mature students, particularly those with children (Read et al. 2003).

15 The concept of risk-because it is both a category of individual rational analysis and also a socially constructed and socially variable perception - may provide a very fruitful location for the rapprochement between Goldthorpe's (1996) rational action theory and Bourdieu's $(1977)$ concept of habitus that Devine $(1998,2004)$ and Hatcher $(1998)$ have called for. For more on risk, see the work of Ulrich Beck (1992) on the rise of a "risk society" and its impact on individuals' self-conceptions. 
But risk and fear also involve social-psychological identities. Many students fear that even if they find HE institutions receptive and they thrive in them this may pose another danger. Many working-class students feel a tension between "solidarist" sentiments of putting great value on ties to family and community and tending to favour institutions that are nearby and allow students to live at home, and "individualist" sentiments of valuing going away and developing a new self that is more highly regarded in society. Those students fear that in succeeding at university, particularly if far from home, they will grow into new identities that their family and community may reject (Archer et al. 2002; Reay 2001, 2005; Reay et al. 2005; Plikuhn and Knoester 2016; see also Jones 2016; Reay et al. 2010).

In addition to being shaped by habitus, students' HE decision making is also shaped by cultural and social capital. Depending on their social backgrounds, students differ greatly in what they know about the costs and benefits of $\mathrm{HE}$, how to finance $\mathrm{HE}$, what the admissions requirements are for different kinds of institutions, and what it takes to be a successful student and successful graduate. These social class and race/ethnic differences in information reflect, among other things, differences in parents' educations, occupations, and social networks and in the quality of careers advising in schools (Archer et al. 2002; Bathmaker et al. 2013; Davies 2012; Devine 2004; Forsyth and Furlong 2003; Hutchings 2003; Leathwood and Hutchings 2003; Reay et al. 2005; Slack et al. 2014; see also Dougherty 2018; Deutschlander 2017).

Government policymakers are aware of the importance of social-class and other differences in information and its impact on student decision making (BIS Department for Business, Innovation and Skills; Diamond et al. 2012, 2014). Still, it is also clear that the various efforts that the government has taken to equalize the provision of information do not address the full complexity of the social stratification of information and what might be necessary to really equalize information access and use (Dougherty and Callender 2017).

\subsection{Explaining the Lack of Evidence of Better Quality and Greater Labour-Market Responsiveness}

Another deficiency of the government's model of student choice is that it fails to specify precisely how greater choice will drive institutions to produce offerings that are of higher quality and more responsive to the demands of the labour market. Even if students are now revenue carriers that institutions feel bound to respond to, will students be able reliably to discern institutional and program quality and choose accordingly? Will students be in a position to pursue subjects of study and attend institutions that produce higher graduate earnings? As it is, there is good reason to argue that students, particularly those whose parents did not go to HE, have greater difficulty determining the quality and labour market utility of HE offerings. HE is a service with a high experience value, so it is hard to judge it before experiencing it. The quality of a HE program depends on the interaction between students, faculty, and the institution, and the relative contribution of each is hard to determine in advance. Finally, the quality and labour market returns of a HE program may take years to become fully apparent (Brown 2018; National Audit Office 2017).

Prospective students whose parents have gone to $\mathrm{HE}$ or who have siblings and peers already at university have some inkling of the $\mathrm{HE}$ factors that produce a high quality experience (Archer et al. 2002; Reay et al. 2005; Slack et al. 2014). However, students whose parents did not attend university will have a more difficult time doing so, particularly if they are entering institutions that are very different from them in predominant class, race, and gender composition and culture and those institutions do little to make explicit their often tacit expectations of students. Hence, working class students will find it harder to determine which institutions and programs are providing higher quality services-particularly to students of their background-and to make appropriate choices.

Moreover, even where students understand and appreciate these quality choices, they still may not be in a position to act on them. Yet, politicians and policy makers seem to assume that with the right information, students are free to choose institutions (i.e., research intensive) and courses (i.e., medicine; dentistry; economics; mathematics; veterinary science) yielding the best graduate earnings 
premium (Gyimah 2018). But these are also the most competitive and entry depends on the highest 'A' Level grades, which are out of reach of the majority of working class students given the existing socio-economic differences in attainment (Vignoles and Crawford 2010). No amount of accurate and transparent information on graduate outcomes will change these realities.

But even where students are good judges of quality, a fundamental obstacle to pursuing quality remains. HE is a positional good, where a good part of its value lies in its relative prestige and scarcity and not in any particular skills, knowledge, and attitudes acquired (Collins 1979; Marginson 2009, 2016b). Hence, even if students were aware that many high-prestige institutions actually are not of high quality in terms of value added, they might still feel constrained to choose those institutions in order to keep themselves in status competition. The result is that the prestige structure is reproduced and institutions feel little pressure from students to improve their quality.

\subsection{Incorrectly Equating Greater Choice With Greater Equality}

Perhaps the most fundamental deficiency of the conventional student-choice model is that it equates greater choice with greater social equality. But as the foregoing has already suggested, this is often not the case. In fact, a neoliberal regime of offering students many choices-while widely seen as desirable and fair-builds on and extends societal disadvantage and does so in a way that obscures that process to virtually all who participate in that regime (Dougherty 2018; see also Marginson 2016a).

The provision of many choices produces social inequality. People often make choices that do not serve their interests as well as they might wish, particularly if they are students who face many choices but are not given adequate information. For example, students often "undermatch," choosing HE institutions and programs that are less challenging and are less likely to advance their careers than they are capable of entering, and these mistaken choices proliferate as students are confronted with more choices (Boliver 2013; Dougherty 2018; Jerrim et al. 2015; Marginson 2016a; Read et al. 2003; Reay 2001; see also Bailey et al. 2015; Deutschlander 2017; Rosenbaum et al. 2006; Smith et al. 2013). For example, Boliver (2013) finds that rates of application to Russell Group institutions in the early 2000 's are substantially lower for manual-class students, even when prior academic preparation is controlled. However, Black and minority ethnic student no longer apply at lower rates once academic preparation is controlled (Boliver 2013).

Secondly, the incidence of these suboptimal choices is not random but is socially stratified. It is higher for less advantaged people, and societal factors-such as the unequal distribution of economic resources, unequal provision of good information, and unequal exposure to discrimination - play a crucial role in producing those socially stratified suboptimal choices (Dougherty 2018; Hutchings 2003; Leathwood and Hutchings 2003; Reay et al. 2005; Slack et al. 2014; see also Deutschlander 2017; Devine 2004; Smith et al. 2013).

Finally, the provision of many choices legitimates social inequality. The more one thinks in terms of choices the more one tends to blame the unfortunate, including oneself, for their circumstances. Seemingly offered many choices in life, both the winners and losers in society come to feel that much of the inequality they experience is due to their own actions and therefore is legitimate (Dougherty 2018; see also Cappelen et al. 2013; Savani and Rattan 2012; Savani et al. 2011; Stephens and Levine 2011). Psychological research finds that those who subscribe to the importance of choice are more likely to blame themselves and experience depression when the results of their choices do not meet their expectations (Dougherty 2018; see also Markus and Schwarz 2010; McClelland and Karen 2009; Savitsky et al. 1997; Wrosch and Heckhausen 2002).

\section{Conclusions}

The analysis of policy rhetoric in government documents clearly demonstrates politicians and policymakers' idealization of student choice, informed by their ideological aspiration to create a quasi-market in HE. Student choice is presented uncritically, with exclusively positive effects and outcomes. The discourse is blind to any negative impacts, and blind to any losers. Student choice 
making is narrowly conceptualized. None of these documents define what they understand by student choice; investigate how students make choices; or explore the very real complexities involved in their choice making. Students are depicted as free from constraints, as unfettered consumers who can choose where, what, and how to study guided principally by the economic costs and benefits of their choices. With funding following students and student loans in their pockets, students allegedly face no material obstacles to realizing their (uniform) HE aspirations and ambitions. In these documents and the choice model they promote, students are presented as a homogeneous and one-dimensional group while their choices are divorced from their socio-economic backgrounds, untouched by social structure and social inequalities.

Student agency is central to the choice model. Students have been given the responsibility for realizing the choice agenda, for expanding participation, for driving up teaching quality and increasing labour market responsiveness through their choice of course and institution. But their constrained choices, perforce, are socially stratified, reproducing and legitimating social inequality. Greater choice does not equate with great equality.

There is little evidence, to date, to suggest that the student choice model, underpinned by higher tuition fees and larger student loans, and so enthusiastically promoted by politicians and policymakers, has fulfilled the promises advanced by them. Undergraduate HE has not expanded following the 2012 student funding reforms and the Browne Report which particularly advocated the student choice model. The number of undergraduate entrants in England has shrunk since 2010 because of the dramatic decline in part-time enrolments. Access to HE has been curtailed and student choice restricted, especially access to part-time and more diverse flexible study. Limited progress has been made in widening HE participation and then only for young full-time entrants. Disadvantaged students are no more likely to enter the most prestigious universities than they were decades ago. HE remains highly stratified, as seen in the enduring class inequalities in access to elite HE. There is limited evidence to suggest enhancements in teaching quality as suggested by the choice model. If anything, student satisfaction with the quality of their course has declined following the 2012 reforms. Labour market outcomes also have not conformed to the government's predictions. Fluctuations in the economy and the labour market principally determine graduate outcomes and are largely outside the control of universities, challenging the call for HE improvements in labour market responsiveness. In reality, student choice and its purported benefits are largely an illusion, bringing into question one of the foundational characteristics of markets, and in turn, the marketization of HE.

It is unlikely that the choice agenda can be rolled back completely. However, the mechanisms underpinning it could be changed to promote greater equality and access. For instance, it is clear that student loans are inappropriate for encouraging part-time study. They have not worked to date. Further reforms to the loan system (the government's strategy) are unlikely to stem the decline in part-time study. At low or zero additional cost per student, the government could give part-time students who are eligible for maintenance loans (from 2018) the option of a tuition fee grant for the first two years of their course instead of having to take out a maintenance loan (Callender and Thompson 2018). This measure would help to reduce price (i.e., fees), liquidity constraints and debt aversion, all of which act as barriers to participation. This approach could be extended to full-time students too.

Improved careers advice, information and guidance in schools and colleges aimed at disadvantaged students could help students' decision making (Dougherty and Callender 2017). More encompassing is the idea of consciously reshaping the 'architecture of choice' in order to make it easier for students to make higher education choices that benefit them. Crucial to such architecture is reducing the number of choices, providing structures that nudge students toward the right choices, and building in supportive defaults if students fail to make a choice or make one not consonant with their interests (Bailey et al. 2015; Dougherty 2018; Dougherty et al. 2017; Thaler et al. 2013).

Ultimately only a full scale attack on social and economic inequalities will eradicate inequalities in HE. As Basil Bernstein said many years ago, education cannot compensate for society. It can only ameliorate and only partially at that. 
Author Contributions: Conceptualization, C.C.; Methodology, C.C.; Formal Analysis, C.C.; Writing-Original Draft Preparation, C.C. and K.D.; Writing-Review \& Editing, C.C. and K.D.

Funding: This research received no external funding.

Conflicts of Interest: The authors declare no conflict of interest.

\section{References}

Altbach, Philip. 1999. The logic of mass higher education. Tertiary Education and Management 5: 107-24. [CrossRef] Archer, Louise, Carole Leathwood, and Merryn Hutchings. 2002. Higher education: A risky business. In Access, Participation, and Higher Education: Policy and Practice. Edited by Annette Hayton and Anna Paczuska. London: Kogan Page.

Arum, Richard, Adam Gamoran, and Yossi Shavit. 2007. More inclusion than diversion: Expansion, differentiation and market structures in higher education. In Stratification in Higher Education: A Comparative Study. Edited by Yossi Shavit, Richard Arum and Adam Gamoran. Stanford: Stanford University Press, pp. 1-35.

Ashwin, Paul, Andrea Abbas, and Monica McLean. 2013. Representations of a high-quality system of undergraduate education in English higher education policy documents. Studies in Higher Education 40: 610-23. [CrossRef]

Bailey, Thomas R., Shanna Smith Jaggars, and Davis Jenkins. 2015. Redesigning America's Community Colleges: A Clearer Path to Student Success. Cambridge: Harvard University Press.

Barnett, Ronald. 2013. The end of mystery and the perils of explicitness. In Browne and Beyond: Modernizing English Higher Education. Edited by Claire Callender and Peter Scott. London: Institute of Education Press.

Bathmaker, Ann-Marie, Nicola Ingram, and Richard Waller. 2013. Higher education, social class, and the mobilization of capitals: Recognising and playing the game. British Journal of Sociology of Education 34: 723-43. [CrossRef]

Beck, Ulrich. 1992. Risk Society: Towards a New Modernity. Los Angeles: Sage Publications.

BIS (Department for Business, Innovation and Skills). 2011. Higher Education: Students at the Heart of the System; Cm. 8122; London: Stationery Office.

BIS (Department for Business, Innovation and Skills). 2016. Success as a Knowledge Economy: Teaching Excellence, Social Mobility and Student Choice; Cm 9258; London: Stationery Office.

Blackmore, Paul, Richard Blackwell, and Martin Edmondson. 2016. Tackling Wicked Issues: Prestige and Employment Outcomes in the Teaching Excellence Framework. Oxford: Higher Education Policy Institute.

Blunkett, David. 2000. Modernising Higher Education: Facing the Global Challenge. Speech. Paper presented at the University of Greenwich, London, UK, February 15.

Boliver, Vikki. 2011. Expansion, differentiation, and the persistence of social class inequalities in British higher education. Higher Education 61: 229-42. [CrossRef]

Boliver, Vikki. 2013. How fair is access to more prestigious UK universities? British Journal of Sociology 64: 344-64. [CrossRef] [PubMed]

Boliver, Vikki. 2015. Lies, damned lies and statistics on widening access to Russell Group universities. Radical Statistics 113: 29-38.

Bolton, Paul. 2018. Student Loan Statistics. Briefing Paper No. 1079. London: House of Commons Library.

Bourdieu, Pierre. 1977. Outline of a Theory of Practice. Cambridge: Cambridge UP.

Bourdieu, Pierre. 1984. Distinction: A Social Critique of the Judgment of Taste. Cambridge: Harvard University Press.

Britton, Jack, Lorraine Dearden, Neil Shephard, and Anna Vignoles. 2016. How English Domiciled Graduate Earnings Vary with Gender, Institution Attended, Subject and Socio-Economic Background. IFS Working Paper W16/06. London, UK: Institute for Fiscal Studies.

Brown, Phillip. 2013. Education, opportunity and the prospects for social mobility. British Journal of Sociology of Education 34: 5-6, 678-700. [CrossRef]

Brown, Roger. 2012. The myth of student choice. Vistas: Education, Economy, and Community 2: 1-14.

Brown, Roger. 2013. Everything for Sale? The Marketization of UK Higher Education. London: Routledge.

Brown, Roger. 2015. The marketization of higher education: Issues and ironies. New Vistas 1: 4-9. 
Brown, Roger. 2018. Neoliberalism, Marketisation and Higher Education: How Neoliberalism is Reshaping the Provision of English Higher Education. Professorial lecture at the University of West London, London, UK, February 27. Available online: https://www.uwl.ac.uk/visit-us/public-lectures/lecture-series / neoliberalism-marketisation-and-higher-education (accessed on 30 July 2018).

Burgess, Simon. 2016. Human Capital and Education: The State of the Art in the Economics of Education. IZA Discussion Paper No. 9885. Bonn: Institute for the Study of Labor (IZA).

Callender, Claire. 2013. Part-time undergraduate student funding and financial support. In Browne and Beyond: Modernizing English Higher Education. Edited by C. Callender and P. Scott. London: Bedford Papers, pp. 130-58.

Callender, Claire, and Jonathan Jackson. 2005. Does fear of debt deter students from HE? Journal of Social Policy 34 : 509-40. [CrossRef]

Callender, Claire, and Geoff Mason. 2017. Does student loan debt deter participation in higher education? New evidence from England. Annals of the American Academy of Political and Social Sciences 671: $20-48$. [CrossRef]

Callender, Claire, and John Thompson. 2018. The Lost Part-Timers: The Decline of Part-Time Undergraduate Higher Education in England. London: Sutton Trust. Available online: https://www.suttontrust.com/researchpaper/lost-part-timers-mature-students / (accessed on 30 July 2018).

Cappelen, Alexander. W., Sebastian Fest, Erik O. Sorensen, and Bertil Tungodden. 2013. Choice and over-attribution of individual responsibility. Paper presented at the CESifo Area Conference on Behavioural Economics, Munich, Germany, October 25-26.

Collins, Randall. 1979. The Credential Society. New York: Seminar Press.

Davies, Peter. 2012. Can governments improve higher education through "informing choice"? British Journal of Educational Studies 60: 261-76. [CrossRef]

Dearden, Lorraine, Emla Fitzsimons, and Gill Wyness. 2010. The Impact of Higher Education Finance on University Participation in the UK; BIS Research Paper 11; London: Department for Business Innovation and Skills.

Dearden, Lorraine, Alissa Goodman, and Gill Wyness. 2012. Higher education finance in the UK. Fiscal Studies 33: 73-105. [CrossRef]

Dearden, Lorraine, Emla Fitzsimons, and Gill Wyness. 2014. Money for nothing: Estimating the impact of student aid on participation in higher education. Economics of Education Review 43: 66-78. [CrossRef]

Deem, Rosemary. 2001. Globalisation, new managerialism, academic capitalism and entrepreurialism in universities: is the local dimension still important? Comparative Education 37: 7-20. [CrossRef]

Department of Trade and Industry. 1998. Our Competitive Future: Building the Knowledge Driven Economy; London: Department of Trade and Industry. Available online: http://webarchive.nationalarchives.gov.uk/+/http: / / www.dti.gov.uk/comp/competitive/wh_int1.htm (accessed on 30 July 2018).

Deutschlander, D. 2017. Academic undermatch: How general and specific cultural capital structure inequality. Sociological Forum 32: 162-85. [CrossRef]

Devine, Fiona. 1998. Class analysis and the stability of class relations. Sociology 32: 23-42. [CrossRef]

Devine, Fiona. 2004. Class Practices: How Parents Help Their Children Get Good Jobs. Cambridge: Cambridge University Press.

DfE. 2018a. Review of Post-18 Education and Funding: Terms of Reference; London: Department for Education. Available online: https://assets.publishing.service.gov.uk/government/uploads/system/ uploads/attachment_data/file/682348/Post_18_review_-_ToR.pdf (accessed on 4 July 2018).

DfE. 2018b. Graduate outcomes (LEO): Employment and Earnings Outcomes of Higher Education Graduates by Subject Studied and Graduate Characteristics; SFR 15/2018; London: Department for Education. Available online: https:/ / assets.publishing.service.gov.uk/.../SFR15_2018_Main_text.pdf (accessed on 24 July 2018).

DFEE. 1998. Blunkett Welcomes Teaching and Higher Education Act; Press Release. London: Department for Education and Employment, July 17.

DfES (Department for Education and Skills). 2003. The Future of Higher Education. Cm. 5735. London: Stationery Office.

Diamond, Abigail, Tim Vorley, Jennifer Roberts, and Stephen Jones. 2012. Behavioural Approaches to Understanding Student Choice. Leicester: CFE Research. 
Diamond, Abigail, Jennifer Roberts, Tim Vorley, Guy Birkin, James Evans, Jonathan Sheen, and Tej Nathwani. 2014. UK Review of the Provision of Information about Higher Education: Advisory Study and Literature Review. Leicester: CFE Research. Available online: http://www.hefce.ac.uk/media/hefce/content/pubs/indirreports/ 2014/Provision,of,information, advisory, study, and,literature,review/2014_infoadvisory.pdf (accessed on 24 July 2018).

Dill, David D. 2007. Will market competition assure academic quality? An analysis of the UK and US experience. In Quality Assurance in Higher Education: Trends in Regulation, Translation and Transformation. Edited by Don Westerheijden. Dordrecht: Springer, pp. 47-52.

Dorsett, Richard, Silvia Lui, and Martin Weale. 2010. Economic Benefits of Lifelong Learning. Discussion Paper No 352. London: National Institute of Economic and Social Research.

Dougherty, Kevin J. 2018. Higher Education Choice-Making in the United States: Freedom, Inequality, Legitimation. Working Paper No 35. London, UK: Centre for Global Higher Education, UCL Institute of Education. Available online: http:/ /www.researchcghe.org/publications/higher-education-choice-making-in-theunited-states-freedom-inequality-legitimation (accessed on 24 July 2018).

Dougherty, Kevin J., and Claire Callender. 2017. English and American Higher Education Access and Completion Policy Regimes: Similarities, Differences, and Possible Lessons. Working Paper \#24. London, UK: Centre for Global Higher Education, UCL Institute of Education, University of London. Available online: http:/ / www.researchcghe.org/publications/english-and-american-higher-education-access-andcompletion-policy-regimes-similarities-differences-and-possible-lessons (accessed on 24 July 2018).

Dougherty, Kevin J., Hana Lahr, and Vanessa S. Morest. 2017. Reforming the American Community College: Promising Changes and Their Challenges. New York: Community College Research Center, Teachers College, Columbia University. Available online: https: / ccrc.tc.columbia.edu/media/k2/attachments/reforming-americancommunity-college-promising-changes-challenges.pdf (accessed on 31 July 2018).

Dynarski, Susan. 2003. Does aid matter? Measuring the effect of student aid on college attendance and completion. American Economic Review 93: 279-88. [CrossRef]

Dynarski, Susan, and Judith Scott-Clayton. 2013. Financial aid policy: Lessons from research. Future of Children 23: 67-91. [CrossRef]

Elias, Peter, and Kate Purcell. 2013. Classifying Graduate Occupations for the Knowledge Society. Futuretrack Working Paper 5. Coventry, UK: Institute for Employment Research, University of Warwick.

Feigenbaum, Harvey, Jeffrey Henig, and Chris Hamnett. 1998. Shrinking the State: The Political Underpinnings of Privatization. New York: Cambridge University Press.

Forsyth, Alasdair, and Andy Furlong. 2003. Socio-Economic Disadvantage and Access to Higher Education. Bristol: Policy Press.

Gibbs, Graham. 2012. Implications of 'Dimensions of Quality' in a Market Environment. York: Higher Education Academy.

Goldthorpe, John M. 1996. Class analysis and the reorientation of class theory: The case of persisting differentials in educational attainment. British Journal of Sociology 47: 481-505. [CrossRef]

Green, Francis, and Golo Henseke. 2016. The changing graduate labour market: Analysis using a new indicator of graduate jobs. IZA Journal of Labor Policy 5: 1-25. [CrossRef]

Green, Francis, and Yu Zhu. 2010. Overqualification, job dissatisfaction, and increasing dispersion in the returns to graduate education. Oxford Economic Papers 62: 740-63. [CrossRef]

Gunn, Vicky, and Anna Fisk. 2013. Considering Teaching Excellence in Higher Education: 2007-2013. York: Higher Education Academy.

Gyimah, Sam. 2018. Delivering value for money in the age of the student. Speech. Paper presented at the HEPI Annual Conference, London, UK, June 7. Available online: https:/ /www.gov.uk/government/speeches/ delivering-value-for-money-in-the-age-of-the-student (accessed on 31 July 2018).

Harvey, David. 2005. A Brief History of Neoliberalism. Oxford: Oxford University Press.

Hatcher, Richard. 1998. Class differentiation in education: Rational choices? British Journal of Sociology of Education 19: 5-24. [CrossRef]

Hazelkorn, Ellen, Hamish Coates, and Alexander C. McCormick. 2018. Research Handbook on Quality, Performance, and Accountability in Higher Education. Cheltenham: Edward Elgar. 
HEFCE. 2014a. UK Review of the Provision of Information about Higher Education. Data for National Student Survey Results and Trends Analysis 2005-2013. Available online: http:/ /www.hefce.ac.uk/data/year/2014/ nsstrends / (accessed on 23 July 2018).

HEFCE. 2014b. Pressure from All Sides: Economic and Policy Influences on Part-Time Higher Education. HEFCE Report 2014/8d. Bristol: Higher Education Funding Council for England.

HEFCE. 2015. Higher Education in England 2015 Key Facts. Available online: www.hefce.ac.uk/.../Analysis/HE, in,England/HE_in_England_2015.pdf (accessed on 19 July 2018).

HEFCE. 2016. Student Characteristics. Available online: http://www.hefce.ac.uk/analysis/HEinEngland/ students / social/ (accessed on 19 July 2018).

HEFCE. 2018. Higher Education in England: Undergraduate Education. Available online: http:/ /www.hefce.ac. uk/analysis/HEinEngland/undergraduate/ (accessed on 19 July 2018).

HESA. 2011a. UK Performance Indicators 2010/11 Widening Participation. Available online: https:/ /www.hesa. ac.uk/data-and-analysis / performance-indicators/releases/2010-11-widening-participation (accessed on 19 July 2018).

HESA. 2011b. Destinations of Leavers From Higher Education in the United Kingdom for the Academic Year 2009/10, statistical First Release SFR162. Available online: https:/ /www.hesa.ac.uk/news/30-06-2011/ sfr162-destinations-of-leavers (accessed on 19 July 2018).

HESA. 2017. Destinations of Leavers from Gigher Education in the United Kingdom for the Academic Year 2009/10, statistical First Release, SFR 245. Available online: https:/ /www.hesa.ac.uk/news/29-06-2017/ sfr245-destinations-of-leavers (accessed on 19 July 2018).

HESA. 2018a. Summary-UK Performance Indicators 2015/16. Available online: https:/ / www.hesa.ac.uk/dataand-analysis/performance-indicators/summary/2015-16 (accessed on 19 July 2018).

HESA. 2018b. Non-Continuation Summary: UK Performance Indicators 2016/17. Available online: https: / / www.hesa.ac.uk/news/08-03-2018/non-continuation-summary (accessed on 31 July 2018).

House of Commons. 2010. Hansard 3 Nov 2010: Column 924. Available online: https://publications. parliament.uk/pa/cm201011/cmhansrd/cm101103/debtext/101103-0001.htm\#10110358000003 (accessed on 31 July 2018).

House of Commons, Committee of Public Accounts. 2018. The Higher Education Market; London: Author.

Hutchings, Merryn. 2003. Information, advice, and cultural discourses of higher education. In Higher Education and Social Class. Edited by Louise Archer, Merryn Hutchings and Alistair Ross. London: Routledge Falmer.

IRHEFSF (Independent Review of Higher Education Funding and Student Finance). 2010. Securing a Sustainable Future for Higher Education: An Independent Review of Higher Education Funding and Student Finance. Available online: http:/ / www.independent.gov.uk/browne-report (accessed on 12 October 2010).

Jerrim, John, Anna K. Chmielewskib, and Phil Parker. 2015. Socioeconomic inequality in access to high-status colleges: A cross-country comparison. Research in Social Stratification and Mobility 42: 20-32. [CrossRef]

Jones, Steven. 2016. Expressions of student debt aversion and tolerance among academically able young people in low-participation English schools. British Educational Research Journal 42: 277-93. [CrossRef]

Labaree, D. 2012. Someone Has to Fail. Cambridge: Harvard University Press.

Land, Ray, and George Gordon. 2013. Enhancing Quality in Higher Education: International Perspectives. New York and London: Routledge, pp. 259-74.

Lareau, A., and A. Cox. 2011. Social class and the transition to adulthood. In Social Class and Changing Families in an Unequal America. Edited by M. Carlson and P. England. Stanford: Stanford University Press, pp. 134-64.

Le Grand, Julian. 2007. The Other Invisible Hand: Delivering Public Services Through Choice and Competition. Princeton: Princeton University Press.

Leathwood, Carolyn, and Merryn Hutchings. 2003. Entry routes to higher education: Pathways, qualifications, and social class. In Higher Education and Social Class. Edited by Louise Archer, Merryn Hutchings and Alistair Ross. London: Routledge Falmer, pp. 137-54.

LFS (Labour Force Survey). 2017. Graduates in the UK Labour Market: 2017; London: Office for National Statistics. Available online: https://www.ons.gov.uk/employmentandlabourmarket/peopleinwork/ employmentandemployeetypes/articles/graduatesintheuklabourmarket/2017\#graduates-and-nongraduates-in-work (accessed on 23 July 2018). 
Mangan, Jean, Amanda Hughes, Peter Davies, and Kim Slack. 2010. Fair access, achievement, and geography: Explaining the association between social class and students' choice of university. Studies in Higher Education 35: 335-50. [CrossRef]

Marginson, Simon. 2009. The Limits of Market Reform in Higher Education. Hiroshima: Research Institute for Higher Education, Hiroshima University; Melbourne: University of Melbourne. Available online: http:/ /www.cshe. unimelb.edu.au/people/marginson_docs/RIHE_17Aug09_paper.pdf (accessed on 30 July 2018).

Marginson, Simon. 2016a. High participation systems of higher education. The Journal of Higher Education 87: 243-71. [CrossRef]

Marginson, Simon. 2016b. The worldwide trend to high participation higher education: Dynamics of social stratification in inclusive systems. Higher Education 72: 413-34. [CrossRef]

Markus, Hazel R., and Barry Schwarz. 2010. Does choice mean freedom and well-being? Journal of Consumer Research 37: 344-55. [CrossRef]

McClelland, Katherine, and David Karen. 2009. Reproduction, redemption, and respect: Analysis. In Ain't No Making It, 3rd ed. Edited by Jay MacLeod. Boulder: Westview Press.

Mullen, Ann. 2010. Degrees of Inequality. Baltimore: Johns Hopkins University Press.

Murphy, Richard, Judith Scott-Clayton, and Gillian Wyness. 2017. The End of Free College in England: Implications for Quality, Enrolments, and Equity. Working Paper No. 30. London, UK: Centre for Global Higher Education, UCL Institute of Education. Available online: http:/ / www.researchcghe.org/publications/the-end-of-freecollege-in-england-implications-for-quality-enrolments-and-equity/ (accessed on 30 July 2018).

Naidoo, R. 2016. Choice in the learning market: Tokenistic ritual or democratic education? In Dimensions of Marketisation in Gigher Education. Edited by Peter John and Joelle Fanghanel. London: Routledge, pp. 38-47.

Naidoo, Rajani, Avi Shankar, and Ekant Veer. 2011. The consumerist turn in higher education policy: Policy aspirations and outcomes. Journal of Marketing Management 27: 1142-62. [CrossRef]

National Audit Office. 2017. The Higher Education Market. London: Author. Available online: https: / /www.nao. org.uk/wp-content/uploads/2017/12/The-higher-education-market.pdf (accessed on 31 July 2018).

NCIHE-National Committee of Inquiry into Higher Education. 1997. Higher Education in the Learning Society. London: HMSO.

OfS. 2018a. What is the TEF? Available online: https:/ /www.officeforstudents.org.uk/advice-and-guidance/ teaching/what-is-the-tef/ (accessed on 19 July 2018).

OfS. 2018b. National Student Survey Results 2018. Available online: https://www.officeforstudents.org.uk/ advice-and-guidance/student-information-and-data/national-student-survey-nss/get-the-nss-data / (accessed on 30 July 2018).

Olssen, Mark, and Michael A. Peters. 2005. Neoliberalism, higher education and the knowledge economy: From the free market to knowledge capitalism. Journal of Education Policy 20: 313-45. [CrossRef]

Perna, Laura. 2006. Studying college choice: A proposed conceptual model. In Higher Education: Handbook of Theory and Research. Edited by John C. Smart. Dordrecht: Springer, vol. 21, pp. 99-157.

Perna, Laura. 2008. Understanding high school students' willingness to borrow to pay college prices. Research in Higher Education 49: 589-606.

Plikuhn, Mari, and Matthew Knoester. 2016. A foot in two worlds. In The 2orking Classes and Higher Education: Inequality of Access, Opportunity and Outcome. Edited by Amy E. Stich and Carrie Freie. New York: Routledge.

Pollard, Emma, Will Hunt, Jim Hillage, Emma Drever, Jenny Chanfreau, Steven Coutinho, and Eloise Poole. 2013. Student Income and Expenditure Survey 2011/12; BIS Research Paper No. 115; London: Department for Business, Innovation and Skills.

Ramsden, Paul, and Claire Callender. 2014. Review of the National Student Survey: Literature Review. Bristol: HEFCE. Available online: http:/ / www.hefce.ac.uk/pubs/rereports/year/2014/nssreview/ (accessed on 22 July 2018).

Read, Barbara, Louise Archer, and Carole Leathwood. 2003. Challenging cultures? Student conceptions of "belonging" and "isolation" at a post-1992 university. Studies in Higher Education 28: 261-77. [CrossRef]

Reay, Diane. 2001. Finding or losing yourself? Working-class relationships to education. Journal of Education Policy 16: 333-46. [CrossRef]

Reay, Diane. 2005. Beyond consciousness? The psychic landscape of social class. Sociology 39: 911-28. [CrossRef]

Reay, Diane, Miriam E. David, and Stephen Ball. 2005. Degrees of Choice: Class, Race, Gender and Higher Education. Stoke on Trent: Trentham. 
Reay, Diane, Gill Crozier, and John Clayton. 2010. 'Fitting in' or 'standing out': Working class students in UK higher education. British Educational Research Journal 36: 107-24. [CrossRef]

Rosenbaum, James, Regina Deil-Amen, and Ann E. Person. 2006. After Admission: From College Access to College Success. New York: Russell Sage Foundation.

Savani, Krishna, and Aneeta Rattan. 2012. A choice mind-set increases the acceptance and maintenance of wealth inequality. Psychological Science 23: 796-804. [CrossRef] [PubMed]

Savani, Krishna, Nicole M. Stephens, and Hazel R. Markus. 2011. The unanticipated interpersonal and societal consequences of choice: Victim blaming and reduced support for the public good. Psychological Science 22: 795-802. [CrossRef] [PubMed]

Savitsky, Kenneth, Victoria H. Medvec, and Thomas Gilovich. 1997. Remembering and regretting: The Zeigarnik effect and the cognitive availability of regrettable actions and inactions. Personality and Social Psychology Bulletin 23: 248-57. [CrossRef]

Scott-Clayton, Judith. 2016. Early Labor Market and Debt Outcomes for Bachelor's Degree Recipients: Heterogeneity by Institution Type and Major, and Trends Over time. New York: Columbia University, Teachers College, Community College Research Center, Center for Analysis of Postsecondary Education and Employment. Available online: https: / ccrc.tc.columbia.edu/publications/early-labor-market-debt-outcomes-bachelorsrecipients.html (accessed on 30 July 2018).

Slack, Kim, Jean Mangan, Amanda Hughes, and Peter Davies. 2014. "Hot," "cold," and "warm" information and higher education decision making. British Journal of Sociology of Education 35: 214-23. [CrossRef]

Slaughter, Sheila, and Gary Rhoades. 2004. Academic Capitalism and the New Economy: Markets, States, and Higher Education. Baltimore: John Hopkins University Press.

Slaughter, Sheila, and Gary Rhoades. 2016. State and markets in higher education. In American Higher Education in the 21st Century. Edited by M. Bastedo, P. M. Altbach and P. Gumport. Baltimore: Johns Hopkins University Press, pp. 503-40.

Smith, Jonathan, Matea Pender, and Jessica Howell. 2013. The full extent of student-college academic undermatch. Economic of Education Review 32: 247-61. [CrossRef]

Stephens, Nicole M., and Cynthia S. Levine. 2011. Opting out or denying discrimination: How the framework of free choice in American society influences perceptions of gender inequality. Psychological Science 22: 1231-36. [CrossRef] [PubMed]

Stich, Amy E., and Carrie Freie. 2016. The Working Classes and Gigher Education: Inequality of Access, Opportunity and Outcome. Abingdon: Routledge.

Student Loans Company. 2017. Student Support for Higher Education in England 2017: 2016/17 Payments, 2017/18 Awards. Statistical First Release 05/2017. Glasgow: Student Loans Company. Available online: https: / / www.slc.co.uk/media/9579/slcsfr052017.pdf (accessed on 31 July 2018).

Thaler, Richard H., Cass Sunstein, and John P. Balz. 2013. Choice architecture. In Behavioral Foundations of Public Policy. Edited by Eldar Shafir. Princeton: Princeton University Press.

Thompson, John, and Bahram Bekhradnia. 2013. The Impact on Demand of the Government's Reforms of Higher Education: The First Evidence on Part-Time Demand and an Update on Fulltime. HEPI Report 62. Oxford: Higher Education Policy Institute. Available online: http:/ /www.hepi.ac.uk/wpcontent/uploads/2014/02/HEPIReport-62-Demand-Report-2013-Full-Report.pdf (accessed on 27 November 2017).

UCAS. 2017. End of Cycle Report 2017. London: UCAS. Available online: https://www.ucas.com/data-andanalysis / ucas-undergraduate-releases / ucas-undergraduate-analysis-reports /2017-end-cycle-report (accessed on 19 July 2018).

Vignoles, Anna, and Claire Crawford. 2010. The importance of prior educational experiences. In Improving Learning by Widening Participation in Higher Education. Edited by Miriam David. Abingdon: Routledge, pp. 47-61.

Wrosch, Carsten, and Jutta Heckhausen. 2002. Perceived control of life regrets: Good for young and bad for old adults. Psychology and Aging 17: 340-50. [CrossRef] [PubMed]

(C) 2018 by the authors. Licensee MDPI, Basel, Switzerland. This article is an open access article distributed under the terms and conditions of the Creative Commons Attribution (CC BY) license (http://creativecommons.org/licenses/by/4.0/). 